Sherwood, Peter. "Introduction: Translating from Hungarian into English." Hungarian Cultural Studies. e-Journal of the American Hungarian Educators Association, Volume 14 (2021): http://ahea.pitt.edu DOI:

10.5195/ahea.2021.431

\title{
Introduction: Translating from Hungarian into English
}

\section{Peter Sherwood}

Which is the most widely translated Hungarian classic? The answer is Imre Madách's (18231864) The Tragedy of Man, which has appeared in forty languages (or to be more precise in forty versions in somewhat fewer languages, as there are at least four in English), placing it about sixty-third on the list of the world's most translated books. And which is the most widely translated English-language classic? It is Alice's Adventures in Wonderland, versions of which exist in more than 170 languages, ranking it eighth on that "most translated books" list. We cannot be sure of the number of copies sold of these titles, but while it is estimated that the Harry Potter series has sold some 500 million copies worldwide and that therefore at least as many people have heard of its author, J.K. Rowling, it may genuinely be wondered how many in the Anglophone world have even heard of Madách, let alone read The Tragedy of Man, in any of its English versions.

These starkly contrasting, if unsurprising, facts and figures sum up in a nutshell the problems facing the translation and dissemination of Hungarian literature in English. Beyond the well-known and considerable linguistic differences lie immense issues of culture, history, genre, and doubtless especially the increasing hegemony of the English language worldwide, which is coupled with the familiar Anglophone reluctance to engage with the literature of - especially smaller nations. It is often claimed that only some three to four percent of the books in all genres published in English are translations, though this figure has been very slightly on the rise in recent years. We need hardly add that works translated from Hungarian make up only a tiny fraction of this already very small percentage, though - again - it does seem that this figure, too, is very slightly on the rise.

The three papers in this cluster are very diverse as regards genre, focus and approach, but what their authors share is a passionate devotion to the promotion of Hungarian literature in the English-speaking world. Translator Anna Bentley surveys the history and present state of the translation of Hungarian children's literature into English and, offering a generous selection of splendid illustrations from the books, persuasively argues that they have as much to offer English-reading children as books from other, better-known, Central European countries, such as Poland and the Czech Republic. She also touches upon the controversy last year surrounding Meseország mindenkié ['Fairytales for Everyone'], a book of fairy tales featuring characters from such marginalized groups as people of color, children in single-parent families, adoptees, as well as LGBTQ+ folk. This volume was very publicly shredded by the deputy leader of one of Hungary's ultra-rightwing parties who claimed, inter alia, that "homosexual princes are not part of Hungarian culture." Anna has been asked to translate the book concerned, Meseország mindenkié, into English: that will certainly be something that attracts attention to Hungarian culture in the Anglophone world.

$(\mathrm{cc}) \mathrm{BY}$

ULLS D-Sente
New articles in this journal are licensed under a Creative Commons Attribution 4.0 International License.

This journal is published by the University Library System of the University of Pittsburgh as part of its D-Scribe Digital Publishing Program and is cosponsored by the University of Pittsburgh Press 
Sherwood, Peter. "Introduction: Translating from Hungarian into English." Hungarian Cultural Studies. e-Journal of the American Hungarian Educators Association, Volume 14 (2021): http://ahea.pitt.edu DOI:

10.5195/ahea.2021.431

Already attracting attention to Hungarian culture, at least among English and American critics and some adventurous readers, is the work of László Krasznahorkai, possibly the bestknown living Hungarian writer, winner of the International Man Booker Prize in 2015. Academic and translator Peter Sherwood subjects one of Krasznahorkai's shorter works, in Ottilie Mulzet's translation, to very close linguistic scrutiny. Perhaps his core concern - in terms formulated by the translation scholar Lawrence Venuti - is how far a translation should be "domesticated," that is, made to fit smoothly into the receiving culture. Alternatively, how far should it be "foreignized," translated into an English that retains elements of the original work but, crucially, how much and how? - thus, perhaps contributing to the (re)vitalization of the target language, English. Broadly speaking the same issue preoccupies translator and theater scholar Jozefina Komporaly in her fascinating account of how she has navigated between the Scylla and Charybdis of these allegedly opposite poles in successfully transferring the work of the Transylvanian Hungarian playwright András Visky onto the British as well as the American stage. The essence of her answer seems to be: by assigning a degree of agency to everyone involved in the process, playwright, translator, director, and performers alike.

While on the face of it an approach such as the one proposed by Komporaly does not appear to be an option available to the literary translator, the contribution of editor(s), copyeditor(s) and even proofreaders to a translated book may be seen as a kind of parallel. There are also other patterns of literary translation not relying solely on an individual, that may become more common in the future, to the benefit of the original work: dual, or even team, translation, for example. These considerations would run counter to a recent trend in some translator circles that claims the (single) translator as a co-author or even - and more controversially - as the creator of an autonomous work.

Translation has been with us since at least the Tower of Babel and continues to attract wide attention to this day. The most recent general book on the subject, Anna Aslanyan's Dancing on Ropes, (London: Profile, 2021), takes its title from John Dryden's 1680 preface to his translation of Ovid's Epistles. It is an early formulation of the eternal dilemma encapsulated by Venuti's terms, an amusing and apt image both for the translator's profession and for ending this introductory note:

It [translation] is like dancing on ropes with fettered legs: a man may shun a fall by using caution, but the gracefulness of motion is not to be expected; and when we have said the best of it, it is but a foolish task; for no sober man would put himself into a danger for the applause of escaping without breaking his neck. 